\title{
FABRICATION AND EVALUTION BIOMASS OVEN PERFORMANCE
}

\author{
${ }^{(1)}$ Gamea, G. R., ${ }^{(2)}$ Taha, A. T., \\ ${ }^{(3)}$ Baiomy, M. A. and ${ }^{(4)}$ EL-Arabie, M. I.
}

ABSTRACT

Biomass oven, which worked with agriculture waste, was fabricated for drying. Hot air was pureed with chemical materials to not be effect dried products with emission.

Four rates combustion $(12.5,25,50$ and 60\%) from combustion chamber volume, the best combustion rate was $25 \%$ as the highest temperature in drying chamber in less time and less $\mathrm{CO}_{2}$ concentration. After chosen the best combustion rate, biomass oven was worked with three air velocities $(1.4$ - 2 and $2.5 \mathrm{~m} / \mathrm{s})$ to choose the best velocity, which achieves the highest temperature and less relative humidity in drying chamber in less time.

It was actuated with the best combustion rate and velocity, thereafter chemical materials were used in the filters to reduce carbon dioxide concentration in the drying chamber air and increase the temperature at an average of $4.5 C^{o}$ is higher than the use without them in filters.

\section{1- INTRODUCTION}

7 he mismanagement of the energy file during the last ten years, due to the stagnation in thought, fear, the inability to development 1 and transformation resist to technologies alternative energy sources (Abo baker,2014). In the past decade, policies to encourage the use of renewable energy have grown in importance as part of the efforts to reduce dependence on non-renewable energy sources such as fossil fuels and as part of strategies to address global warming. Wood energy has been identified as a potentially significant source of renewable energy, and for this reason a number of developed countries have shown interest in increasing its use (Trossero, 2002).

\footnotetext{
(1) Professor of Agric. Eng. Dept., Fac. Ag., Menoufia University., Egypt.

${ }^{(2)}$ Associate professor of Agric. Eng. Dept., Fac. Ag., Menoufia University., Egypt.

(3) Chief Research in Agricultural Engineering Institute, Agricultural Research Center, Dokk

(4) Design engineer and post graduate student Fac. Ag., Menoufia University.
} 
Biomass is the third largest primary energy in the world, after coal and oil. It can be used to produce produces gas which can be used to generate power by gas (Bapat et al.,1997).

Agricultural waste was collected from different farms, that waste are barley straw, bean husk, leaves reeds, rice straw, corncobs, cotton strove, corn roods, casing, corn stalks and wheat straw. These nine waste account for about $65.6 \%$ from total amount of waste crops resulting at Egypt in (El-Zhabe, 1997).

Combustion is the 1989 most developed and most frequently applied process used for solid biomass fuels because of its low cost and high reliability. The interest in using biomass residue pellets for heating purposes is increasing. (Gravalos et al.,2010).

The rate of combustion is also important in the design of combustion systems. Occasionally, biomass combustion power plants have been observed to be under designed in terms of boiler volume and grate area for the rated capacity. Typical design heat release rates (expressed per unit grate area), for a stoker fired travelling grate combustor are in the range of 2 to $4 \mathrm{MW}$ (thermal) $\mathrm{M}^{-2}$ (Jenkins et al., 1998).

Biomass furnaces exhibit relatively high emissions of $\mathrm{NO}_{\mathrm{X}}$ and particulates in comparison to furnaces with natural gas or light fuel oil. Hence, they contribute significantly to particulate matter (PM), ozone, and NO2 in the ambient air. For wood combustion, a life cycle assessment (LCA) indicates that $38.6 \%$ of the environmental impact of a modern automatic wood furnace is attributed to $\mathrm{NO}_{\mathrm{X}}, 36.5 \%$ to $\mathrm{PM} 10$, only $2 \%$ to $\mathrm{CO}_{2}$ and $22.9 \%$ to all other pollutants 7 the LCA for wood, light fuel oil, and natural gas also shows that the environmental impact of wood is higher than that for natural gas for a standard valuation of the greenhouse effect. Hence, improvements in the wood chain are necessary. (Nussbaumer et al., 2003).

Hall et al.,2005 reported that the oven consists of following parts, A chimney to remove smoke from the kitchen, an enclosed fire to retain the heat, careful design of pot holder to maximize the heat transfer from fire, baffles to create turbulence and hence improve heat transfer, dampers to control and optimize the air flow, a ceramic insert to minimize the rate of heat loss, a grate to allow for a variety of fuel to be used and ash to be 
removed, metal casing to give strength and durability and multi pot systems to maximize heat use and allow several pots to be heated simultaneously.The institutional rocket stoves are able to achieve maximum transfer of heat to the food because they heat at least $90 \%$ of the saucepan surface area and have insulation around the combustion chamber and fire passages. The institutional rocket stoves are made in two versions, the fixed rocket stoves and the mobile rocket stoves. Fixed rocket stoves are built in permanent shelters using bricks and mortar for the body work. (Kabuleta et al., 2004).

\section{The present study was conducted with the following objectives:}

1- Development a biomass oven to allow drying of agricultural products using agricultural waste

2-Evaluate biomass oven performance through without load experiments.

\section{MATERIALS AND METHODS}

\section{Fabrication Biomass Oven}

Biomass oven consists of three main parts as shown in figures (1) and (2) which are: combustion chamber, drying chamber and linking chamber which were developed to produce cheap energy.

Combustion chamber was used to burn the biomass material after that send the generated heat by follow air through it to air filter before pushing this air to drying chamber containing the material to be dried. The internal and external walls of this chamber were made of $2.5 \mathrm{~mm}$ and $1 \mathrm{~mm}$ thickness steel metal respectively and the space between the two walls were insulated by glass wool. The internal and external dimensions of combustion chamber were (high $40 \mathrm{~cm}$ length $50 \mathrm{~cm}$ width $50 \mathrm{~cm}$ ), (high $60 \mathrm{~cm}$ length $70 \mathrm{~cm}$ width $70 \mathrm{~cm}$ ) respectively.

Drying chamber was formed from steel metal same the previous chamber. In this chamber the agricultural product were dried by heat which comes through copper pipes. Before heat reaches the drying chamber, it passes to the filter to pure it. Drying chamber and combustion chamber was connected by the filters. The chamber has two drying racks, the racks placed between top and bottom pipes to receive the heat from copper pipes which have $10 \mathrm{~m}$ length and $3 / 4$ inch diameter. Heating breaks were set up in combustion chamber to isolate and protect sheets metal from 
erosion. The internal and external dimensions of drying chamber were (45 $\mathrm{cm}$ high, $100 \mathrm{~cm}$ length and $40 \mathrm{~cm}$ width) and $(65 \mathrm{~cm}$ high, $120 \mathrm{~cm}$ length and $60 \mathrm{~cm}$ width) respectively.
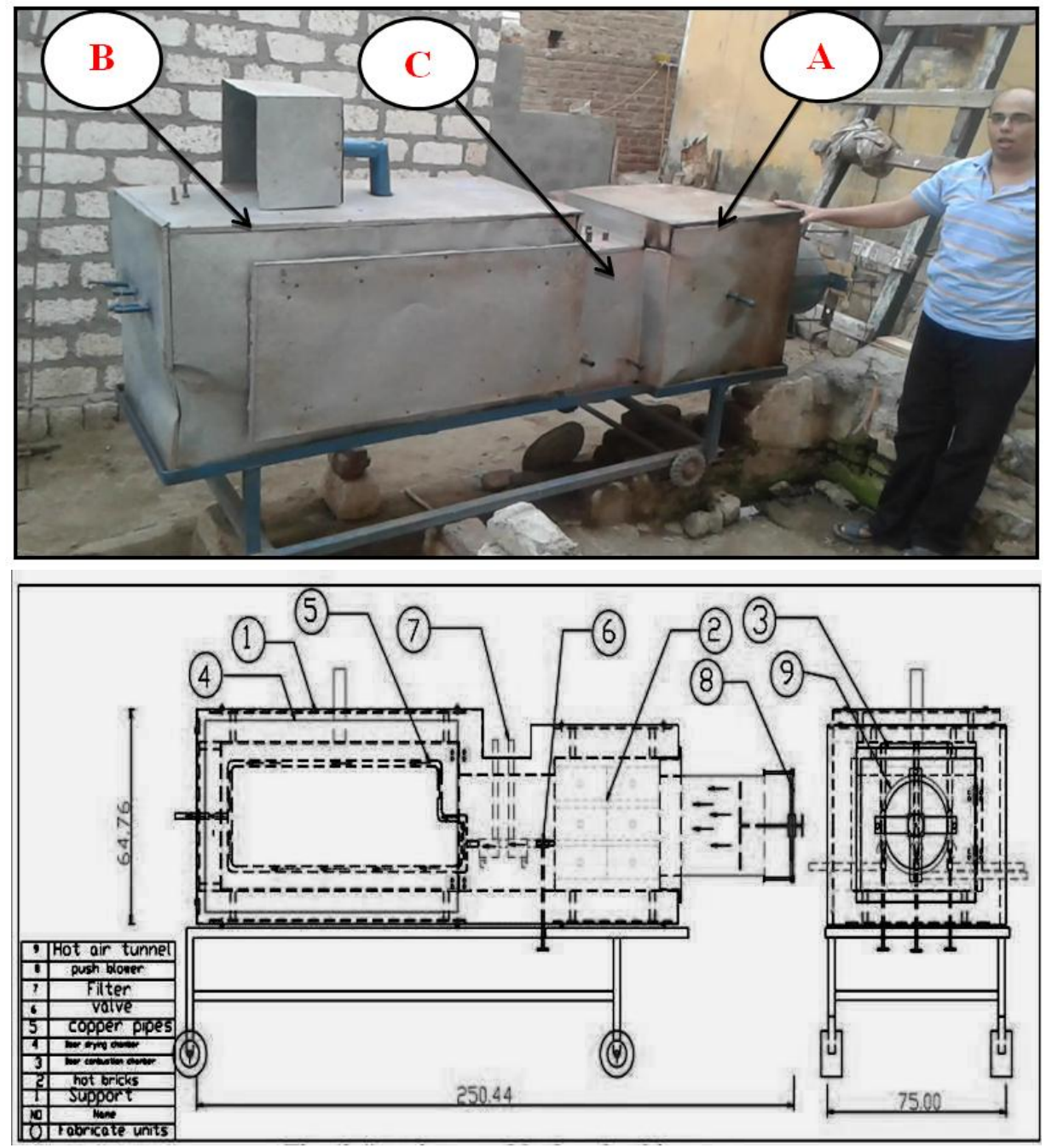

Figure (1) Main parts of biomass oven (A) Combustion chamber,(B) Drying chamber, $(C)$ Linking chamber

Linking chamber in (B.O) was located between combustion and drying chambers. In this chamber contain the filters that reduce the $\mathrm{Co}_{2}$ ratio as well as valves that control the flow at hot air inside the heating pipes. The internal and external dimensions of linking chamber were $(30 \mathrm{~cm}$ high, 45 $\mathrm{cm}$ length and $30 \mathrm{~cm}$ width) and $(50 \mathrm{~cm}$ high, $30 \mathrm{~cm}$ length and $50 \mathrm{~cm}$ width) respectively. 
Steel metal sheets and plated tin were used to fabricate the internal and external body at (B.O) all sides were set up to shape the oven.

The insulation (glass wall $10 \mathrm{~cm}$ thick) was used between internal and external oven bodies to prevent heat leakage from the (B.O) body. Thermal conductivity coefficient $(\mathrm{K})$ is $0.04 \mathrm{w} / \mathrm{m} . \mathrm{k}$

Air blower was fixed on combustion chamber to increase oxygen in hot air tunnel which fixed on a combustion chamber door to distance air blower from hot air flow rate . The biomass oven positioned a suitable steel chassis.

Two chemical materials were used in filters to purify the hot air coming from combustion chamber to drying chamber.

The first material was iron oxide which decreased Co; it is chemical formula $\mathrm{Fe}_{2} \mathrm{O}_{3}$, whose trade name is hematite. Its iron ratio is $70 \%$, its atomic weight is (100 gm), and its purity is $96 \%$. This chemical material was taken from Chinese International Trading Company, (Alexandria, Egypt, in year 2014).The second material is Hydro oxide calcium (H.O.C) which decreased $\mathrm{Co}_{2}$, it is chemical formula $\mathrm{Ca}(\mathrm{OH})_{2}$, whose trade name was Hydrated lime and the atomic weight is (54 gm). Sultan Company Alexandria, Egypt, in year 2015).

\section{Evaluate Biomass oven performance}

Corncobs (working material) were used to produce heating in biomass oven, corncobs $\left(237.24 \mathrm{~kg} / \mathrm{m}^{3}\right)$ have high quality more than another agricultural waste, this is due to the Carbon Dioxide emission exiting from corncobs which is less than emission exiting from the other agricultural waste $\left(\mathrm{Co}_{2}=0.9313 \mathrm{Kg} \mathrm{Co}_{2} / \mathrm{kg}\right.$ corncobs $)$. The vapor $\left(\mathrm{H}_{2} \mathrm{O}\right)$ is higher than another agricultural waste. The chemical reaction chance inside filters is more than other agricultural wastes when vapor $\left(\mathrm{H}_{2} \mathrm{O}\right)$ is highly. $\left(\mathrm{H}_{2} \mathrm{O}=0.9791 \mathrm{Kg}\right.$ water $/ \mathrm{kg}$ corncobs $)$. the protein ratio in corncobs is less than the other agricultural waste. So it is not used in animals feeding. The maximum and minimum heating values are16.58 and 14.17 MJ/kg respectively (EL-Zahbe, 1997).

The experiments were without load with another meaning, biomass oven was worked without drying agricultural products, which the best parameters were chosen to actuate biomass oven to dry agricultural products with agricultural wastes. Experiments without load are very 
important to select the best combustion rate from four rates were selected as shown in table (3.2), which achieve the highest temperature and the lowest carbon dioxide concentration. The combustion rate is also important in the combustion chamber design, which has been developed according to agricultural waste (corncobs) according to (Jenkins et al., 1998). After choosing the best rate of the combustion, velocity experiments were done to choose the best velocity from three velocities (1.4 - 2 and 2.5$) \mathrm{m} / \mathrm{s}$. The best velocity is that materialization of the highest temperature $\left({ }^{0} \mathrm{C}\right)$ and less relative humidity $(\%)$ in drying chamber. This velocities were selected according to EL-Mesery and Mao, (2016).After choosing the best combustion rate and the best velocity, (B.O) was actuated with chemical experiments to choose the best method (without chemical materials and with them) without load experiments and trough them to know the effects of the chemical materials on the air quality in drying chamber.

Table (3.2) corncobs weight at different combustion chamber volumes ratios:

\begin{tabular}{|c|c|}
\hline Corncobs weights & Volumetric ratio related to \\
\hline $9 \mathrm{~kg}$ & $60 \%$ \\
\hline $7.5 \mathrm{~kg}$ & $50 \%$ \\
\hline $3.75 \mathrm{~kg}$ & $25 \%$ \\
\hline $1.75 \mathrm{~kg}$ & $12.5 \%$ \\
\hline
\end{tabular}

\section{RESULTS AND DISCUSSIONS}

\section{Evaluation of biomass oven without load:-}

To choose the best conditions which are used with biomass oven and are as follow air temperature, combustion time and with $\mathrm{Co}_{2}$ concentration.

\section{Combustion chamber air temperature}

Figure (4) shows the relationships between the temperature in combustion chamber and the combustion time for the different amount of corncobs as a volumetric ratio related the combustion volume (12.5, 25, 50 and 60\%).

From this figure we can illustrated that the temperatures were increased by increased in the corncobs amount and the average values were (162, 199, 408 and $\left.503 \mathrm{C}^{\circ}\right)$ for $(12.5,25,50$ and $60 \%)$ respectively. And the maximum values occurred at 30 minutes from burning start and then 
decreased gradually to $\left(140,155,250\right.$ and $\left.250{ }^{\circ} \mathrm{C}\right)$ for $(12.5,25,50$ and $60 \%$ ) respectively.

\section{Time of combustion}

Figure (5) shows the relationship between combustion time and the corncobs amount as volumetric ratio related to combustion volume. We can obtain that this time was increased by amount increased and it are values (90, 120, 210 and 240 minutes) for (12.5, 25, 50 and 60\%) respectively

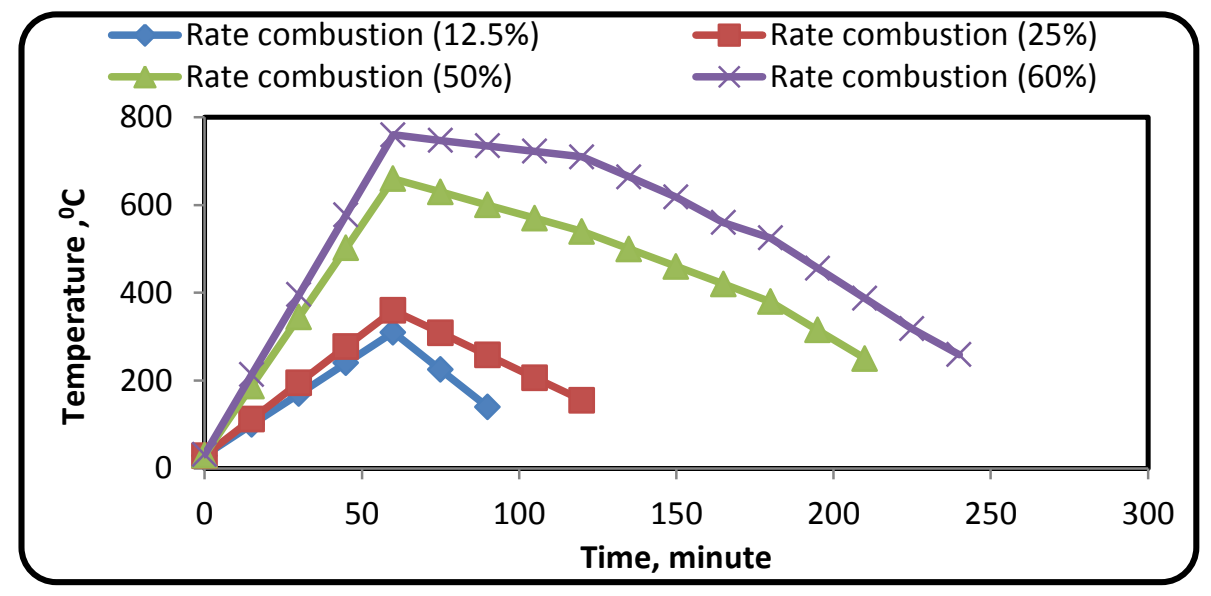

Figure (4) Combustion chamber temperature related to combustion time.

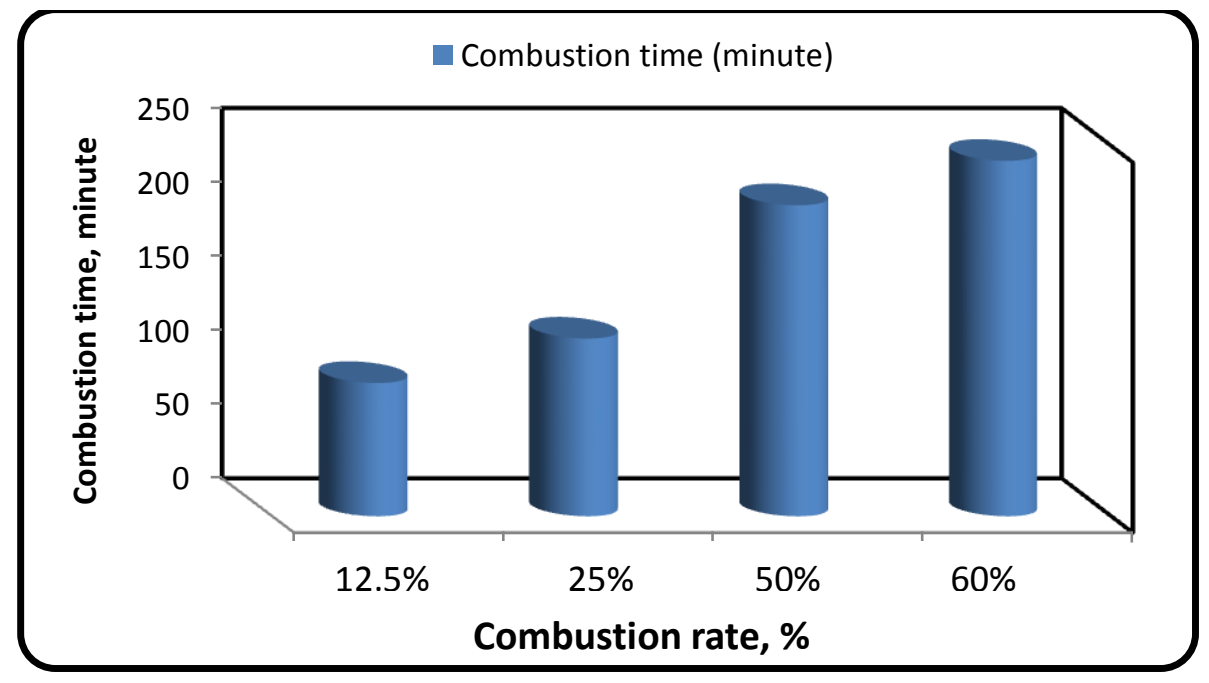

Figure (5) Combustion time for volumetric ratios from volume of combustion chamber 


\section{Select the air velocity.}

Choosing the best air velocity, are the highest temperature and the little relative humidity. From figure (6) and (7) the best velocity is $2.5 \mathrm{~m} / \mathrm{s}$ because the temperature inside the drying chamber is higher than the other velocities. The least relative humidity and the least combustion time in drying chamber are $\left(46.5 \mathrm{C}^{\circ}, 21 \%\right.$ and 120 minute) respectively compared with the other two experiments. In experiment (2), the velocity of combustion is $2 \mathrm{~m} / \mathrm{s}$ the temperature is low and the relative humidity is high in more time in drying chamber are $\left(42 \mathrm{C}^{\circ}-29 \%\right.$ and 150 minute) respectively. In the experiment (3) the velocity of combustion is $1.4 \mathrm{~m} / \mathrm{s}$, the temperature is lower and the relative humidity is higher in more time in the drying chamber are $\left(39{ }^{\circ} \mathrm{C}-31.5 \%\right.$-180minute) respectively.

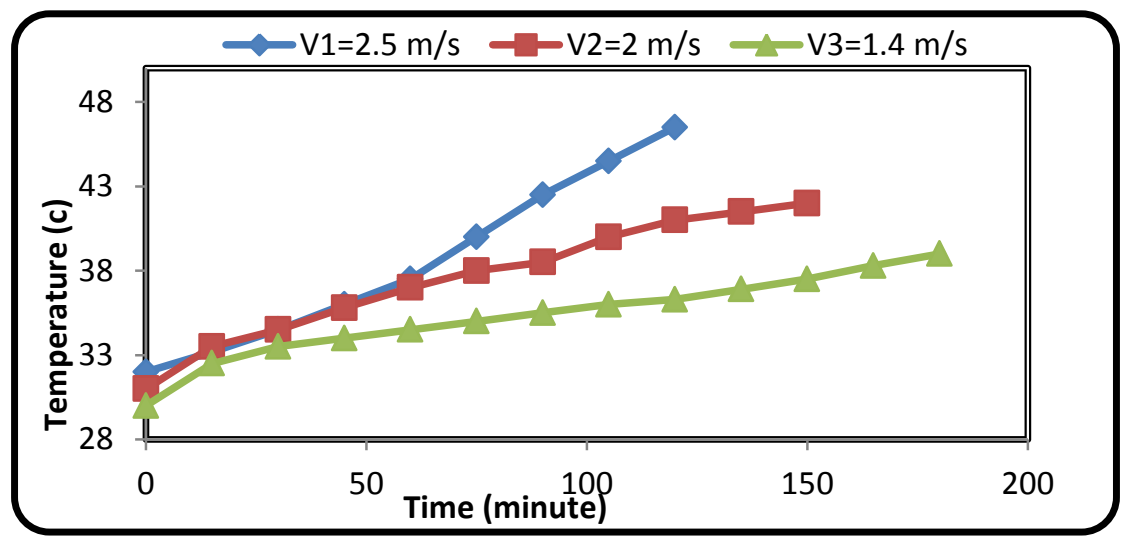

Figure (6) Drying chamber temperatures were at three different velocities

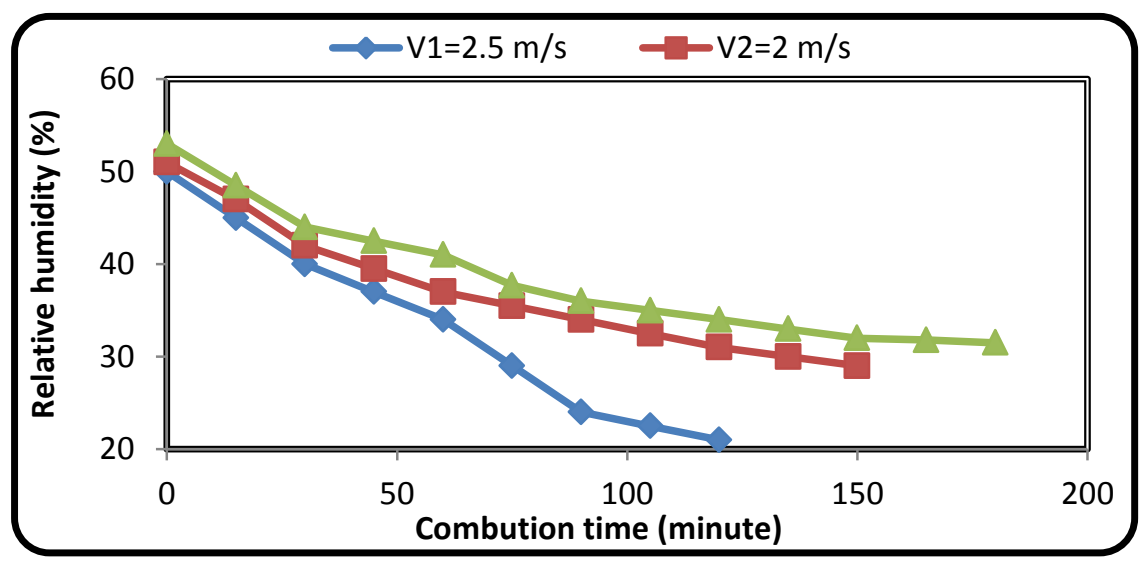

Figure (7) Drying chamber relative humidity at three different velocities 


\section{Air characteristics of drying chamber without load at used air velocity}

\section{$(2.5 \mathrm{~m} / \mathrm{s})$.}

Air characteristics in drying chamber are very important because they have high affect on drying products in biomass oven. These characteristics in drying chamber are air temperature, air relative humidity and $\mathrm{Co}_{2}$ concentration.

\section{Air temperature of drying chamber:-}

Figure (8) present the relationship between air temperatures $\left({ }^{\circ} \mathrm{C}\right)$ and combustion time (minute) when used the different amount of corncobs as volumetric ratios related to combustion chamber volume. From this figure we can obtained that by increase the volumetric ratio lead to an increase in combustion chamber temperatures and it increased by combustion time increase.

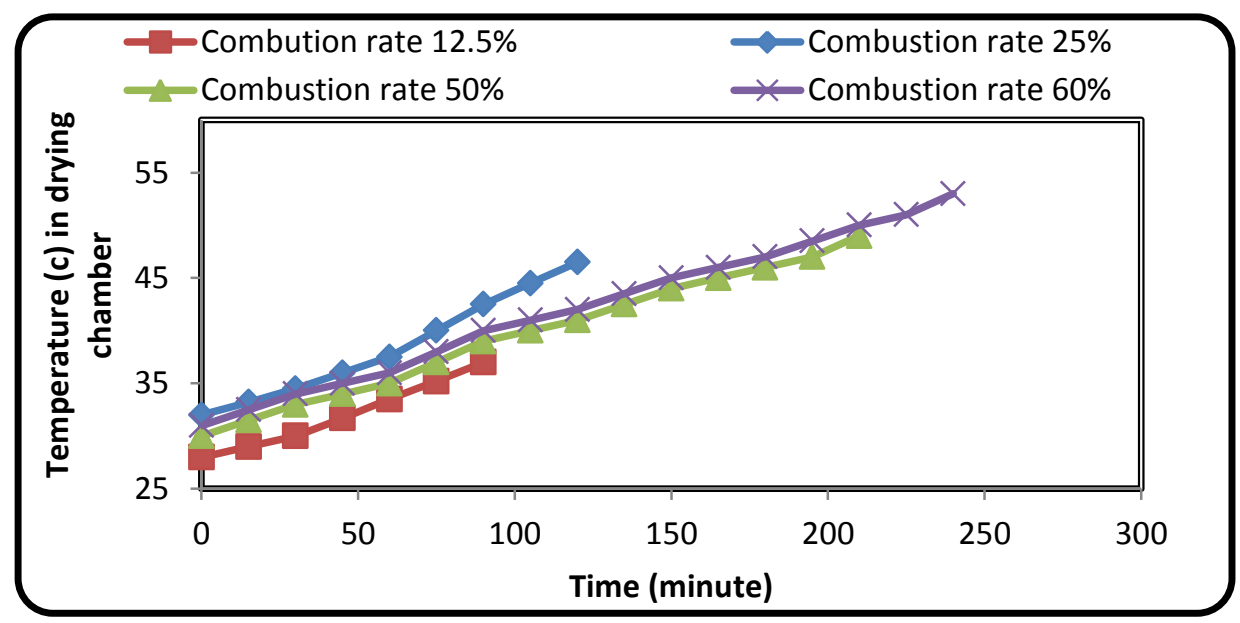

Figure (8) Drying chamber temperature related to combustion time with different combustion rate.

Also Figure (8) and table (A.1) illustrated that when use the volumetric ratio $(\mathbf{1 2 . 5 \%})$ after 30 minutes from combustion started was increased to $30 \mathrm{C}^{\mathrm{o}}$. And at the end of 90 minutes, the temperature was increased to 37 $\mathrm{C}^{\mathrm{o}}$. The ambient air temperature is $28 \mathrm{C}^{\circ}$.

When use the volumetric ratio (25\%), after 30 minutes the temperature was increased to $32.5 \mathrm{C}^{\mathrm{o}}$ and at the end of 120 minutes the temperature was increased to $46.5 \mathrm{C}^{0}$ compared with the ambient air temperature which is $32 \mathrm{C}^{0}$. When use the volumetric ratio (50\%), after 45 minutes the 
temperature was increased to $34{ }^{\circ} \mathrm{C}$ and at the end of 210 minutes the temperature was increased to $50 \mathrm{C}^{\mathrm{o}}$ compared with the ambient air temperature which is $31 \mathrm{C}^{\mathrm{o}}$.

When use the volumetric ratio $(\mathbf{6 0 \%})$, after 45 minutes the temperature was increased to $35{ }^{\circ} \mathrm{C}$ and at the end of 240 minutes the temperature was increased to $53{ }^{\circ} \mathrm{C}$ compared with the ambient air temperature which is 30 $\mathrm{C}^{\mathrm{o}}$.

Finally from figure (9), the highest temperature occurred at used $60 \%$ volumetric ratio was increased by $7.5 \%, 12.26 \%$ and $30.18 \%$ than using the volumetric ratios $50 \%, 25 \%$ and $12.5 \%$.

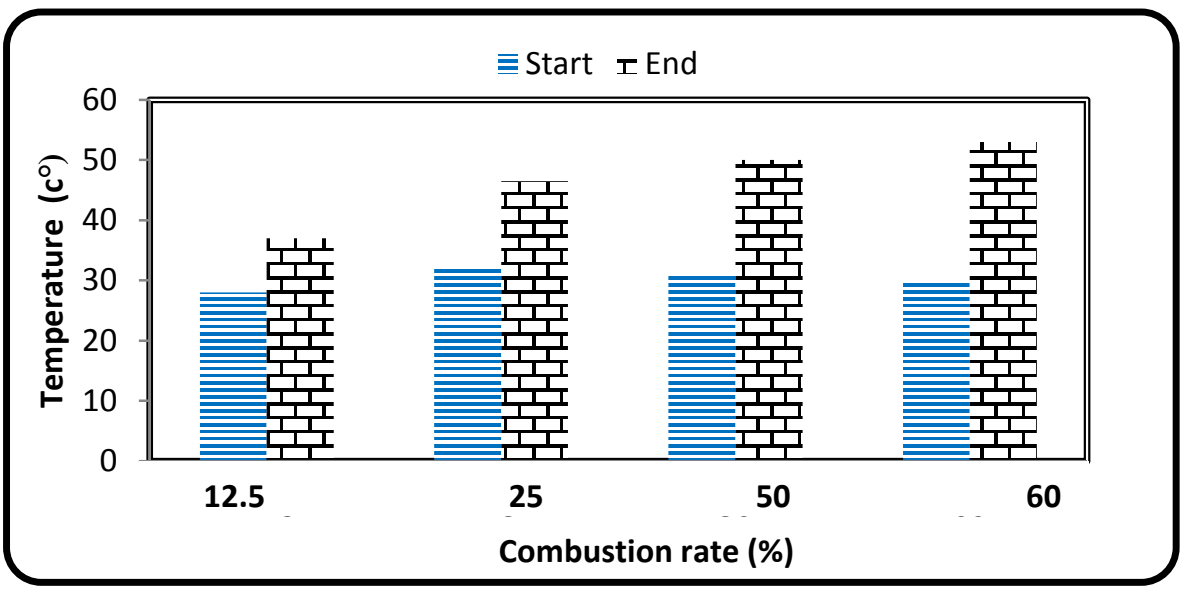

Figure (9): The temperature of the beginning and end of the experiments.

\section{Air relative humidity of drying chamber:-}

Figure (10) present the relationship between air relative humidity (\%) and combustion time (minute) when used the different amount of corncobs as volumetric ratios related to combustion chamber volume. From this figure, we can obtained that by increase the volumetric ratio lead to a decrease in combustion chamber relative humilities and it decreased by combustion time increase. Also Figure (10) and table (A.1) illustrated that when use the volumetric ratio (12.5\%) after 30 minutes from combustion started was decreased to $41 \%$. And at the end of 90 minutes, the relative humidity was decreased to $35 \%$, compared with relative humidity of ambient air which is $50 \%$.

When use the volumetric ratio (25\%), after 30 minutes the relative humidity was decreased to $40 \%$. And at the end of 120 minutes, the 
relative humidity was decreased to $21 \%$ compared with relative humidity of ambient air which is $50 \%$.When use the volumetric ratio $\mathbf{5 0 \%}$ ), after 45 minutes the relative humidity was decreased to $34 \%$. And at the end of 210 minutes the relative humidity was decreased to $20 \%$ compared with relative humidity of ambient air which is $54 \%$. When use the volumetric ratio $(\mathbf{6 0 \%})$, after 45 minutes the relative humidity was decreased to $39.7 \%$. And at the end of 240 minutes the relative humidity was decreased to $17 \%$ compared with the ambient air temperature which is $53 \%$. Finally from figure (11), the lowest relative humidity occurred at used $60 \%$ volumetric ratio was decreased by $-17.64 \%,-23.52 \%$ and $105.88 \%$ than using the volumetric ratios $50 \%, 25 \%$ and $12.5 \%$

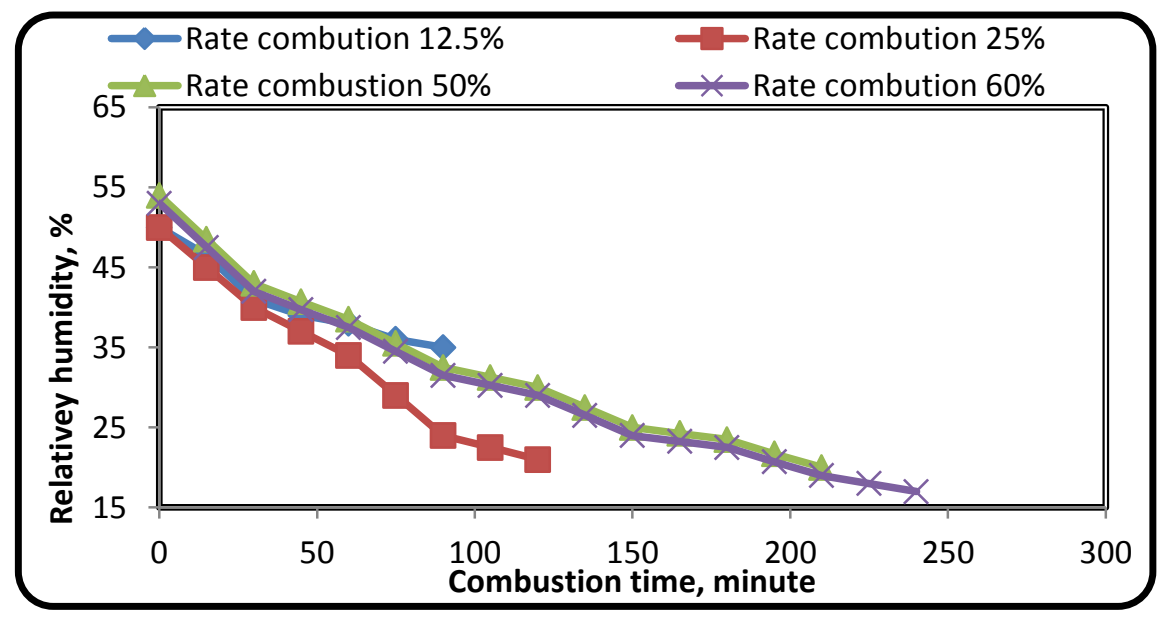

Figure (10) Drying chamber relative humidity related to combustion time with different combustion rate.

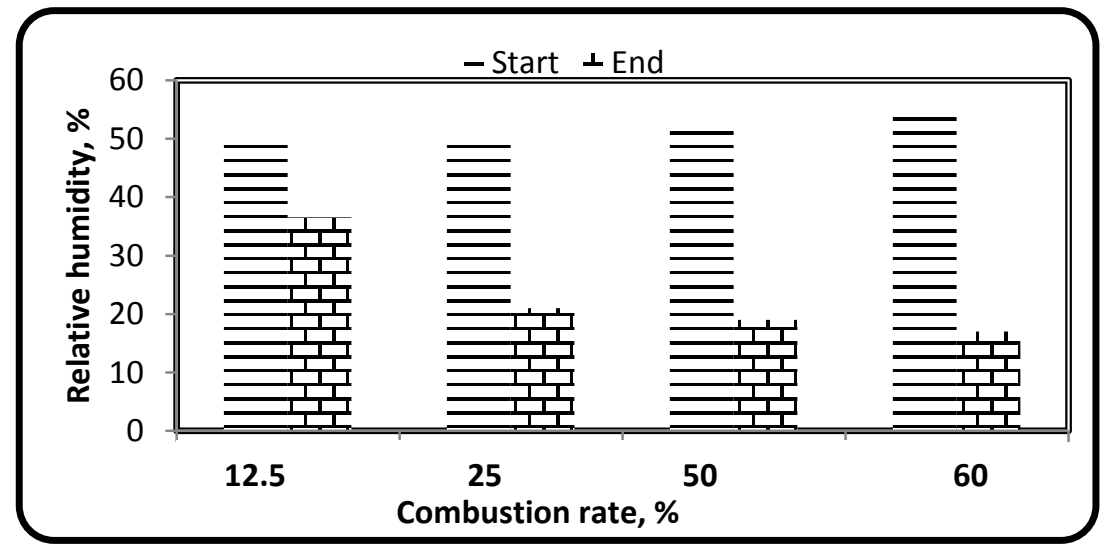

Figure (11): The relative humidity of the beginning and end of the experiments. 


\section{$\mathrm{Co}_{2}$ concentration of the air inside drying chamber:-}

Concentration of $\mathrm{Co}_{2}$ and combustion time when use the volumetric ratio $25 \%$. From figure (12), we can obtain that the filter had a main effect on the concentration of $\mathrm{Co}_{2}$. And this concentration decreased when use the chemical materials in the filters. The values of $\mathrm{Co}_{2}$ in drying chamber without chemical materials in filter was $480 \mathrm{ppm}$ at the end of the combustion, and $433 \mathrm{ppm}$ when use the chemical materials in filter. This means that the filter decreased the $\mathrm{Co}_{2}$ concentration by $9.79 \%$ at the end of combustion.

After 30 minutes the $\mathrm{Co}_{2}$ concentrations was $950 \mathrm{pmm}$ in drying chamber without use chemical materials in filters and when use chemical materials in filters was $490 \mathrm{ppm}$. This means that the filter decreased the $\mathrm{Co}_{2}$ concentration by $48.5 \%$.

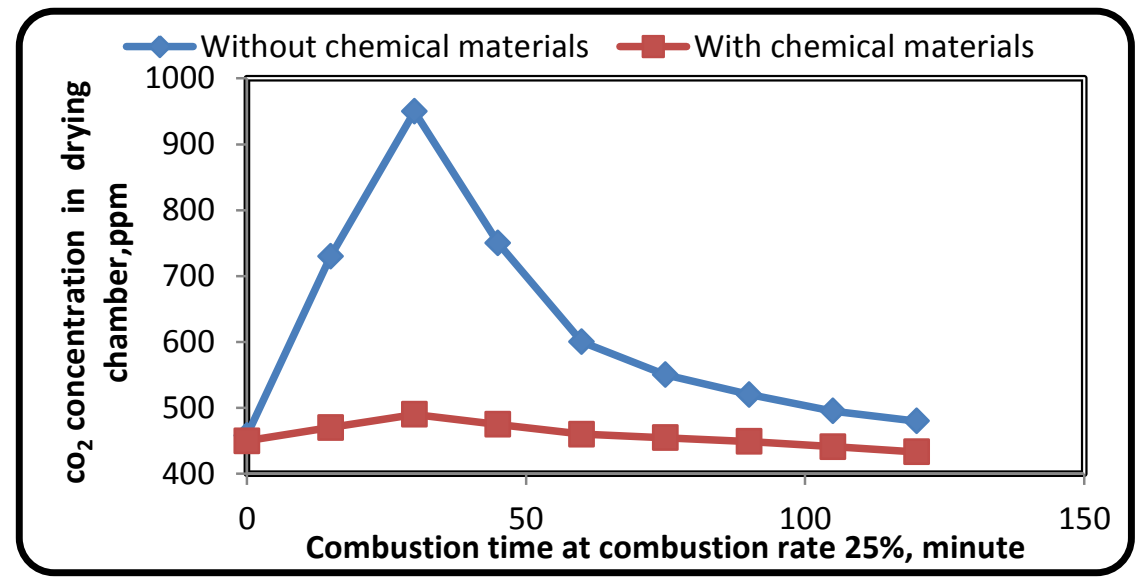

Figure (12) Carbon dioxide $\mathrm{CO}_{2}$ concentration in drying chamber (ppm) with and without chemical materials at volumetric ratio $25 \%$

Figure (13) present the relationship between $\mathrm{Co}_{2}$ concentration (ppm) and combustion time (minute) when used the different amounts of corncobs as volumetric ratios related to combustion chamber volume. From this fig. we can obtained that by increase the volumetric ratio lead to a increase in combustion chamber $\mathrm{Co}_{2}$ concentration.

Also Figure (13) and table (A.1) illustrated that when use the volumetric ratio $(\mathbf{1 2 . 5 \%})$ after 30 minutes from combustion started was increased to $460 \mathrm{ppm}$. And at the end of 90 minutes, the $\mathrm{Co}_{2}$ concentration was decreased to $433 \mathrm{ppm}$. 


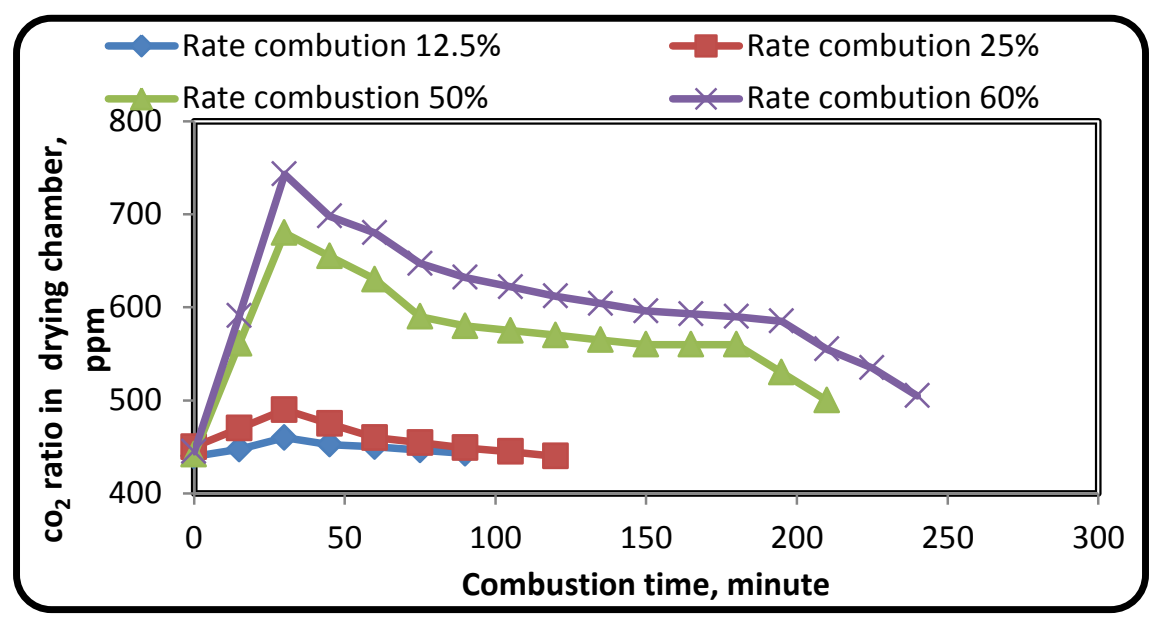

Figure (13) Drying chamber carbon dioxide $\left(\mathrm{CO}_{2}\right)$ related to combustion time with different combustion rates.

When use the volumetric ratio (25\%), after 30 minutes the $\mathrm{Co}_{2}$ concentration was increased to $490 \mathrm{ppm}$. And at the end of 120 minutes, the $\mathrm{Co}_{2}$ concentration was decreased to $440 \mathrm{ppm}$. When use the volumetric ratio (50\%), after 45 minutes the $\mathrm{Co}_{2}$ concentration was increased to 655 ppm. And at the end of 210 minutes the $\mathrm{Co}_{2}$ concentration was decreased to $500 \mathrm{ppm}$. When use the volumetric ratio $(\mathbf{6 0 \%})$, after 45 minutes the $\mathrm{Co}_{2}$ concentration was increased to $698 \mathrm{ppm}$. And at the end of 240 minutes the $\mathrm{Co}_{2}$ concentration was decreased to $505 \mathrm{ppm}$. From figure (13), the $\mathrm{Co}_{2}$ concentration maximum occurred at used $60 \%$ volumetric ratio was increased by $0.99 \%, 12.87 \%$ and $12.2 \%$ than using the volumetric ratios $50 \%, 25 \%$ and $12.5 \%$.Finally from figure (14), the $\mathrm{Co}_{2}$ concentration in the end of combustion occurred at used $60 \%$ volumetric ratio was increased by $6.16 \%, 29.79 \%$ and $34.09 \%$ than using the volumetric ratios $50 \%, 25 \%$ and $12.5 \%$

From previous results conclusions, the best conditions which used in biomass oven. The choice of the best volumetric ratio reached to the highest temperature in the least time and the least $\mathrm{CO} 2$ concentration agreeing with (Olsson, 2006), the best volumetric ratio was $25 \%$ because the highest temperature in drying chamber in the least time and the $\mathrm{CO} 2$ concentration also was minimum, compared with the other three 
experiments. But in experiment (1) the volumetric ratio was $12.5 \%$, the temperature was very low in the least time and also the minimum of $\mathrm{CO} 2$ concentration in drying chamber.

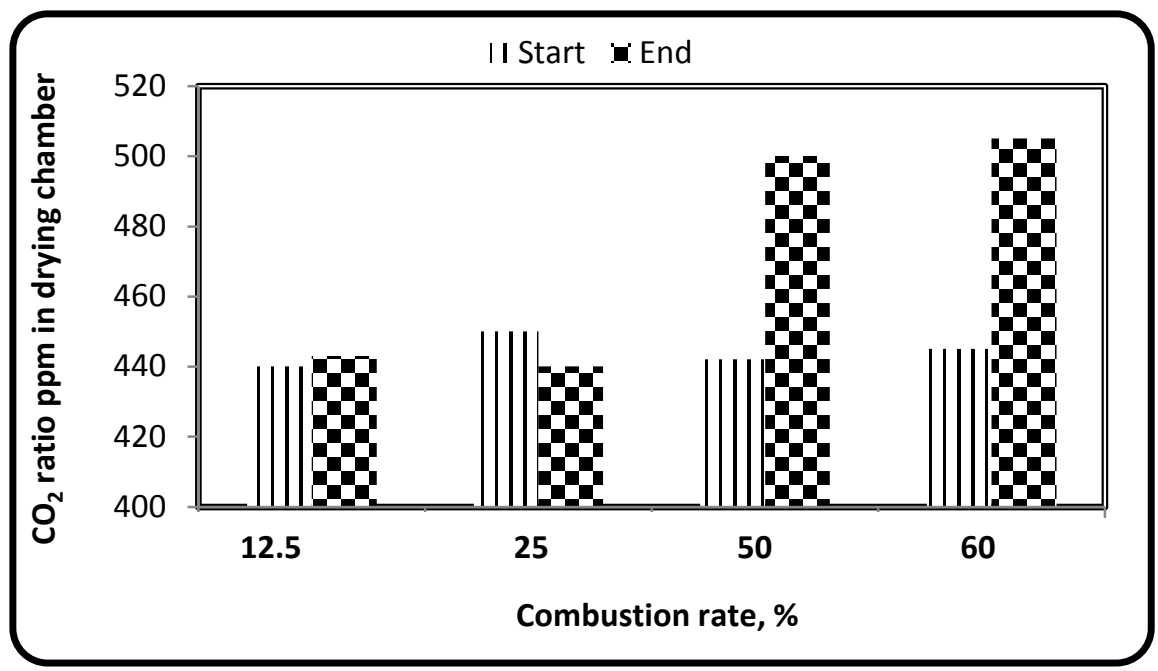

Figure (14): The carbon dioxide $\left(\mathrm{CO}_{2}\right)$ concentration of the beginning and end of the experiments.

In the experiment (3) the volumetric ratio was $50 \%$, the temperature and $\mathrm{CO}_{2}$ concentration were high in a longer time in the drying chamber. In the experiment (4) the volumetric ratio was $60 \%$, temperature and $\mathrm{CO}_{2}$ concentration were higher in a longer time but that was not the best combustion rate because $\mathrm{CO}_{2}$ concentration and the time were higher. The previous results were in agreement with Abuelnuor et all, (2014) and Han chienlin, (2008) in $\mathrm{CO}_{2}$ concentration relation with combustion time.

\section{CONCLUSION}

Biomass oven is friendly environmental as emission from carbon dioxide and carbon monoxide were reduced by chemical materials, The study recommends using a biomass oven for safely dispose from agricultural waste. The Biomass oven can be used to dry agricultural products when using a $25 \%$ from combustion chamber volume, where it is given the highest temperature increase. 


\section{REFERENCES}

Abo baker, T. (2014). "The Energy Future in Egypt". Federation of Egyptian industries, The Committee on Energy and the Federation of Industry in Egypt.

Trossero, M. A. (2002). Wood energy: the way ahead. Unasylva, (also available at www.fao.org/forestry/unasylva), (211): 3-12

Bapat, D. W.; Kulkarni, S. V. and Bhandarkar, V. P. (1997). "Design and operating experience on fluidized bed boiler burning biomass fuels with high alkali ash". In: Preto FDS, editor. Proceedings of the 14th international conference on fluidized bed combustion, New York: Vancouver ASME; p. 165-74.

EL-Zahbe, A. (1997). "Application Biomass". These PhD, Department agriculture engineering, Faculty agriculture, Cairo University

EL-Mesery, H.S and H. Mao (2016). "Characteristics of onion slices dried using microwave and infrared radiation". Journal of Scientific Research and Development. 3 (3).page; 104-111

Gravalos, I.; Kateris, D.; Xyradakis, P.; Gialamas, T.; Loutridis, S.; Augousti, A.; Georgiades, A. and Tsiropoulos, Z. (2010). "A study on calorific energy values of biomass residue pellets for heating purposes". Forest Engineering: meeting the needs of the society and the environment,PadovaItaly

Jenkins, B. M.; Baxter, L. L.; Miles, T. R. and Miles, T. R. (1998). "Combustion properties of biomass". Fuel Processing Technology,(54)page :17-46.

Nussbaumer, T. A. and Verenum, L. C. (2003). "Combustion and Cocombustion of Biomass" Fundamentals, Technologies, and Primary Measures for Emission Reduction,(17); 1510-1521

Hall, B. (2005). "Biomass". practical action Technology challenging poverty. http://practicalaction.org/,(27/11/2016).

Kabuleta, K. R.; Mugerwa, L.; Mutyaba, J. and Mubbala, R. (2004). "Technical Diagrams and Photography". Ministry of energy and mineral development. 
الملخص العربى

\section{تصنيع وثقيم اداع فرن البيوماس}

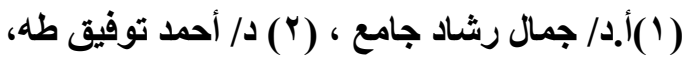

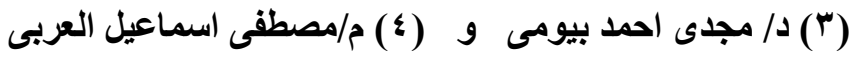

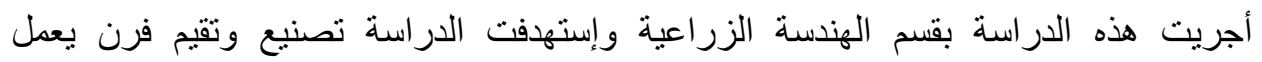

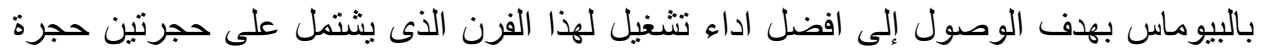

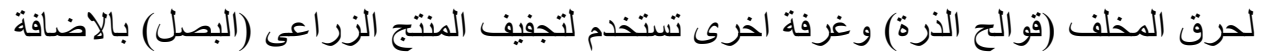
الى غرفة بينية لفلتر الهواء. وتم قياس افضل اداء تشغيلى : باجهزة لقياس الحرارة وغرال الرطوبية

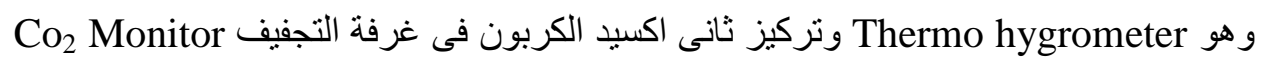

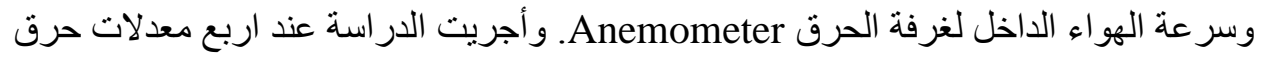

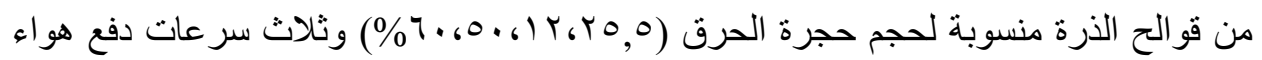

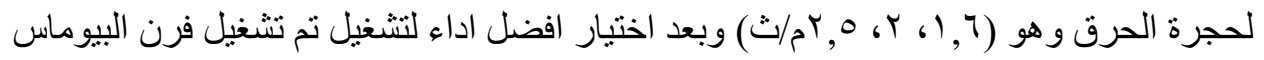

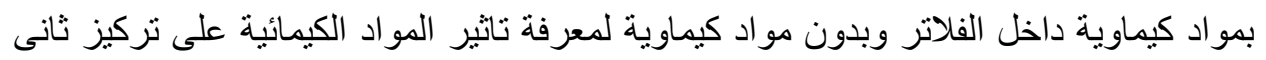

اكسيد الكربون فى حجرة التجفيف. وتوصلت الدراسة إلى النتائج الآتية:

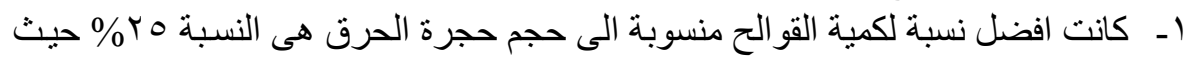

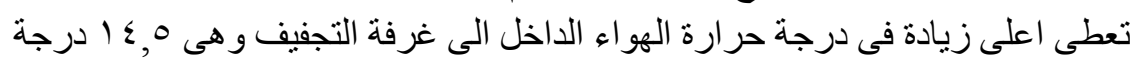

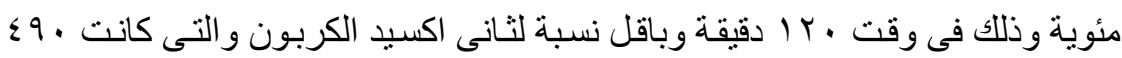
جزء لكل مليون.

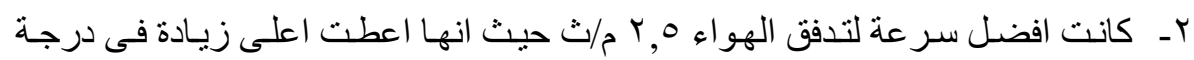

حرارة الهواء المار فى غرفة التجفيف.

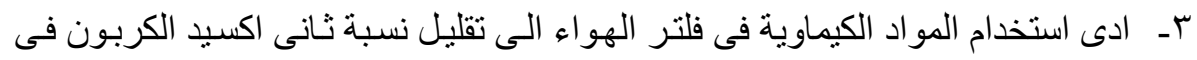

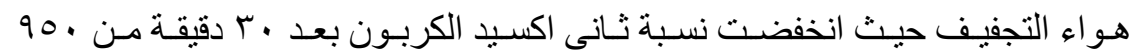

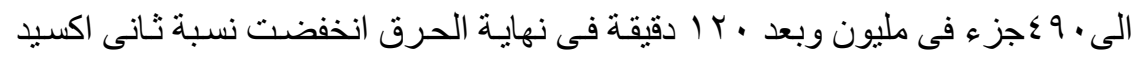

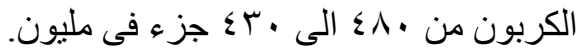

(1) (1) أستاذ بقسم الهندسة الزراعية ـ كلية الزراعة - جامعة المنوفية.

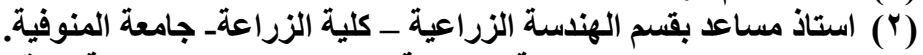

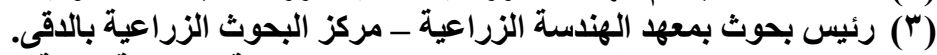

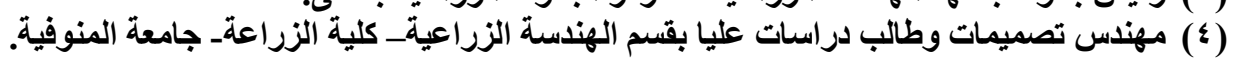

